Çukurova Üniversitesi Mühendislik Mimarlık Fakültesi Dergisi, 34(3), ss. 35-48, Eylül 2019

Çukurova University Journal of the Faculty of Engineering and Architecture, 34(3), pp. 35-48, September 2019

\title{
Hayvan Gübresinden Biyogaz Üretim Potansiyelinin Belirlenmesi: Adana İli Örnek Hesaplama
}

\author{
Hüseyin YAĞLI"1, Yıldız KOÇ¹ \\ ${ }^{1}$ İskenderun Teknik Üniversitesi, Mühendislik ve Doğa Bilimleri Fakültesi, Makine \\ Mühendisliği Bölümü, İskenderun, Hatay
}

$\ddot{\mathbf{O} z}$

Geliş tarihi: 16.05.2019 Kabul tarihi: 30.09 .2019

Bu çalışmada, Adana İli için biyogaz üretimi ve üretilen bu biyogazın kullanımı ile elde edilebilecek güç miktarının tespiti yapılmıştır. Çalışma kapsamında öncelikle Adana ilinde bulunan tüm hayvan sayıları (kanatlı, büyük ve küçük baş) elde edilerek bu hayvanların günlük gübre miktarları bulunmuştur. Bulunan gübre miktarı ve hayvan türüne göre gübre içerikleri dikkate alınarak üretilebilecek biyogaz miktarı hesaplanmıştır. Son olarak, üretilebilecek biyogaz miktarına bağlı olarak elde edilecek güç miktarı bulunmuştur. Hesaplamalar sonucunda Adana ilindeki hayvanlardan elde edilen gübrenin oksijensiz ortamda çürütülmesi ile yıllık ortalama biyogaz üretimi 88.367,417 $\mathrm{m}^{3}-\mathrm{CH}_{4} / \mathrm{yll}$ olarak ve bu biyogazın kullanımı ile yıllık yaklaşık elektrik enerjisi üretimi 309,286 MWhe/yıl olarak hesaplanmıştır.

Anahtar Kelimeler: Adana, Biyogaz, Hayvan gübresi, Hayvansal atık, Biyogazdan güç üretimi

\section{Determination of Biogas Production Potential from Animal Manure: A Case Calculation for Adana Province}

\begin{abstract}
In this study, biogas production and the amount of power that can be obtained by using this biogas were determined. Within the scope of the study, first of all animal numbers (poultry, cattle and small cattle) in Adana province were obtained and daily manure quantities of these animals were found. The amount of biogas that can be produced by considering the manure content and the amount of manure according to the type of animal was calculated. Finally, the amount of power to be obtained was determined depending on the amount of biogas that can be produced. As a result of the calculations, the annual average biogas production was calculated as $88.367 .417 \mathrm{~m}^{3}-\mathrm{CH}_{4} /$ year and the annual electric energy production was calculated as 309.286 MWhe/year with the use of this biogas.
\end{abstract}

Keywords: Adana, Biogas, Animal manure, Animal waste, Power production from biogas

*Sorumlu yazar (Corresponding author): Hüseyin YAĞLI, huseyin.yagli@iste.edu.tr 


\section{GíRiș}

Dünya nüfusunun artmasına paralel olarak ve sanayinin gelişmesi enerji talebini artırmakta olup mevcut enerji arzı bu talebi karşılayamamasından dolayı enerji fiyatları yükselmektedir. Buda gittikçe enerji kullanımı artması anlamına gelmektedir. Dünya enerji ihtiyacını karşılamak için yoğun bir şekilde kullanılan fosil yakıt rezervlerinin sınırlı olmaları nedeniyle iler ki yıllarda gerekli enerji ihtiyacını karşılamakta sıkıntılar çekileceği açıkça görülmektedir. Hizlı bir şekilde artan enerji ihtiyacının karşılanması için ülkemizde ve Dünyada yenilenebilir enerji kaynaklarına olan talep hızlı bir şekilde artış göstermektedir.

Nüfus artışına bağlı olarak organik içerikli atıkların miktarında da artış gözlenmektedir. Çevresel açıdan olumsuz etki oluşturan bu atıkların bertaraf edilmesi zorunluluğu ortaya çıkmaktadır. Yeni enerji kaynakları arayışı içerisinde organik atıkların hem bertaraf edilmesi hem de biyogaz üretiminde kullanılarak alternatif enerji kaynağı olarak değerlendirilmesi gittikçe önem kazanmaktadır. Organik temelli atıklardan enerji üretimi hem fosil yakıt kullanımını azaltırken aynı zamanda çevresel yönden olumsuz etkileri ortadan kaldırılmaktadır. Türkiye için yapılan araştırmalarda biyokütle atıklarından elde edilebilecek enerji miktarı 8,6 milyon TEP olarak ve bu atıkların çürüme kuyularında oksijensiz ortamda sindirilmesi ile elde edilebilecek biyogaz miktarının 1,5 ile 2 milyon TEP civarına olacağ tahmin edilmiştir [1]. Mevcut durumda $811 \mathrm{MW}$ üretim kapasitesine ulaşmış olan kurulu biyokütle kaynaklı güç üretim tesislerinden 2018 yilında yaklaşık 3216 GWh elektrik üretimi gerçekleşmiştir [1].

Biyokütle ve biyo-atıkların çürütülmesi ile elde edilebilecek bu büyük güç üretim potansiyeli araştırmacıları biyogaz üretimi ve biyogazdan güç üretim sistemlerine yöneltmiştir. Taleghani ve Kia [2], yapmış oldukları çalışmada organik atıklardan biyogaz eldesini ekonomik ve teknik yönden Saveh biyogaz güç tesisini baz alarak incelemişlerdir. Shane ve arkadaşları [3], yapmış oldukları çalışma kapsamında kentsel ticari biyogaz güç üretim modelini Zambiya kasabaları için uygulayarak teknik yönden incelemişlerdir. León ve Martín [4], hayvan gübresinden biyogaz üretim potansiyelini incelemiş oldukları çalışmada aynı zamanda üretilen bu biyogazdan güç elde edilebilmesi için farklı güç sistemi tasarımları da yapmışlardır. Çalışma kapsamında öncelikle seçilen bölgedeki hayvan gübre miktarlarını tespit etmiş ve bu gübreden elde edilebilecek biyogaz miktarını hesaplamışlardır. Sonrasında gaz türbini ve Rankine çevriminden oluşan bir kojenerasyon sistemi kullanarak bu biyogazdan elde edilebilecek güç miktarını hesaplamışlardır. Çalışma sonucunda 2,6 MW güç üretilebileceği görülmüştür.

Noorollahi ve arkadaşları [5], İran için besi hayvanlarının gübresinden elde edilebilecek biyogaz potansiyelini hesaplamışlardır. Çalışma sonucunda İran'in Sistan-Baluchestan ve Ilam bölgelerinin yüksek gaz tüketimi ve devasa biyogaz üretim potansiyelinden dolayı öncelikli biyogaz üretim bölgeleri olması gerektiği kanaatine varmışlardır.

Abdeshahian ve arkadaşları [6], Malezya bölgesinde bulunan çiftliklerdeki hayvanların gübrelerinden elde edilebilecek biyogaz potansiyeli üzerine yapmış oldukları çalışmada, Malezya çiftliklerindeki hayvan gübrelerinden y1llık 4589,49 milyon- $\mathrm{m}^{3} / \mathrm{y} 1$ biyogaz üretilebileceğini hesaplamışlardır. Benzer şekilde Avrupa bölgesindeki hayvan çiftlikleri için de bir çalışma Scarlat ve arkadaşları [7] tarafından yapılmıştır. Çalışma kapsamında yapılan hesaplamalar neticesinde 13.866 ile 19.482 arasinda biyogaz üretim tesisinin Avrupa bölgesine kurulabileceğini ve bu tesislerin kurulması neticesinde $6144 \mathrm{MWe}$ ile $7145 \mathrm{MWe}$ arasında bir elektrik üretiminin mümkün olduğunu hesaplamışlardır. Biyogaz üretimi ve üretilen biyogazın güç sistemlerinde kullanımı üzerine yapılan çalışmaların yanı sıra bu tesislerden elde edilen toplam verimi arttırmak içinde birçok çalışma mevcuttur. Bu çalışmalar mevcut güç sistemlerinin optimizasyonunun içermesinin yanı sıra mevcut güç sistemlerine atık 1s1 geri kazanım sitemlerinin entegre edilmesiyle de elde edilen toplam verimi artırmayı hedeflemektedir [8-10].

Tüm bu çalışmalar bir arada ele alındığında bölgesel biyogaz üretim potansiyelinin 
araştırılmasının ve bu potansiyel neticesinde elde edilebilecek güç miktarının belirlenmesinin ülke politikaları ve ekonomik sürdürülebilirlik açısından önemi açıkça görülmektedir. Ayrıca, literatür çalışmalarında dünya ülkelerinde o ülkenin genel ve şehirler bazında biyogaz üretim potansiyelinin araştırıldığı birçok çalışma görülürken Türkiye için yapılmış kısıtlı çalışma olduğu anlaşılmaktadır. Türkiye'nin genel biyogaz üretiminin yanı sıra hayvan sayısı bakımından büyük potansiyele sahip olan şehirlerin de potansiyelinin belirlenmesi büyük bir önem arz etmektedir.

Bu çalışmada Adana bölgesi için biyogaz üretim potansiyeli ve elde edilen bu biyogazdan üretilebilecek güç miktarı araştırılmıştır. Çalışma kapsamında öncelikle Adana bölgesinde bulunan kanatlı, büyükbaş ve küçük baş hayvan sayılarının tespiti yapılmış ve bu hayvanların günlük gübre üretimleri baz alınarak üretilen günlük ve yıllık gübre miktarları hesaplanmıştır. Sonrasında her bir hayvanın gübre içeriği ve biyogaz üretim potansiyeli göz önüne alınarak üretilebilecek biyogaz potansiyeli tespit edilmiş olup bu biyogazın kullanımı ile üretilebilecek güç miktarı hesaplanmıştır.

\section{BİYOGAZ}

Organik içerikli atıklardan biyogaz üretimi sonucunda enerji ihtiyacının bir kısmı karşılanırken diğer yandan atıkların bertaraf edilmesini sağlanmaktadır. Ana bileşen olarak proteinleri, karbonhidratları, hemiselülozları ve selülozları içeren her türlü biyokütle, biyogaz üretiminde kullanılabilir [11].

Biyokütle kullanımıyla; katı, sıvı ve gaz olarak farklı formlarda enerji ürünleri üretilebilir. Biyokütle kullanımı 6 farklı metotta olabilir. Bunlar, gazlaştırma, anaerobik çürütme, piroliz, doğrudan yakma, biyoyakıt üretimi ve kömür yakıtlarıyla beraber kullanılması sonucu enerji üretimi sağlanmaktadır [12].

Biyogaz oksijensiz ortamda organik artıkların biyolojik süreçlerle parçalanması sonucu elde edilir. Biyogazın farklı şekillerde yapılan anaerobik işlemlerle ortaya çıkan temel bileşikler Metan ve Karbondioksit karışımı olup bunlar toplam gazın hacimsel olarak yaklaşık \%98'ini oluştururlar. Ayrıca Biyogaz içerisinde az miktarda $\mathrm{N}_{2}, \mathrm{O}_{2}, \mathrm{H}_{2} \mathrm{O}$, $\mathrm{H}_{2} \mathrm{~S}, \mathrm{H}_{2}$ ve $\mathrm{NH}_{3}$ gibi maddelerde bulunur [13]. Biyogazın bileşimi, sindirim süresi, atığın türü ve biyogaz üretim proses şartlarına bağlıdır. Biyogazın başlıca bileşeni metan gazı olup temel bileşenleri Çizelge 1'de verilmiştir.

Çizelge 1. Biyogazın temel bileşenleri [14]

\begin{tabular}{|l|c|c|}
\hline Bileşen Adı & $\begin{array}{c}\text { Hacimsel } \\
\text { Oran }\end{array}$ & Birim \\
\hline Metan $\left(\mathrm{CH}_{4}\right)$ & $40-75$ & $\%$ \\
\hline Karbon dioksit $\left(\mathrm{CO}_{2}\right)$ & $15-60$ & $\%$ \\
\hline Su buharı $\left(\mathrm{H}_{2} \mathrm{O}\right)$ & $1-5$ & $\%$ \\
\hline Azot $\left(\mathrm{N}_{2}\right)$ & $0-5$ & $\%$ \\
\hline Oksijen $\left(\mathrm{O}_{2}\right)$ & $<2 \%$ & $\%$ \\
\hline Hidrojen $\left(\mathrm{H}_{2}\right)$ & $<1$ & $\%$ \\
\hline Amonyak $\left(\mathrm{NH}_{3}\right)$ & $0-500$ & $\mathrm{ppm}$ \\
\hline $\begin{array}{l}\text { Hidrojen Sülfür } \\
\left(\mathrm{H}_{2} \mathrm{~S}\right)\end{array}$ & $0-5000$ & $\mathrm{ppm}$ \\
\hline
\end{tabular}

Biyogaz oluşumunda açığa çıkan metan gazı ideal bir gaz olup sıvılaştırma basıncı 280-350 bar olduğundan LPG gibi kolay sıvılaştırılamamaktadır. $1 \mathrm{~m}^{3}$ biyogazın ısıl değeri içerisindeki metan oranına bağlı olarak 4700 ile $5700 \mathrm{kcal}$ arasında değişir. $1 \mathrm{~m}^{3}$ biyogaz 0.75 litre benzin, 0.66 litre motorin, $0.25 \mathrm{~m}^{3}$ propan, $0.2 \mathrm{~m}^{3}$ bütan gazı, $1.46 \mathrm{~kg}$ odun kömürü, $3.47 \mathrm{~kg}$ odundan sağlana enerjiye eşdeğerdir [15]. Biyogaz üretimi için gerekli olan bileşenler; organik madde, bakteri, anaerobik ortam ve isidir [16].

Biyogazın en temel bileşeni olan metan oluşumunu sağlayan bakterilerin besin maddesi organik maddedir. Organik maddenin en önemli kaynağ 1 ise tarımsal ve hayvansal kökenli atıklardır. Bunlar; tarımsal atıklar, bahçe atıkları, kentsel katı atıklar, gıda ve yemek atıkları hayvansal gübre ve hayvansal atıkları, sanayi ve kentsel atık su arıtma tesis çamurları, gıda endüstrisi atıkları (çikolata, maya, süt vb.), sebze-meyve işleme atıkları ile bazı endüstriyel atıklar (tekstil, kağıt, deri, orman, gıda, vb.) organik madde kaynağ 1 olarak kullanılmaktadır. [17]. Biyogazın üretim aşamaları Şekil 1'de şematik olarak verilmiştir [18]. 


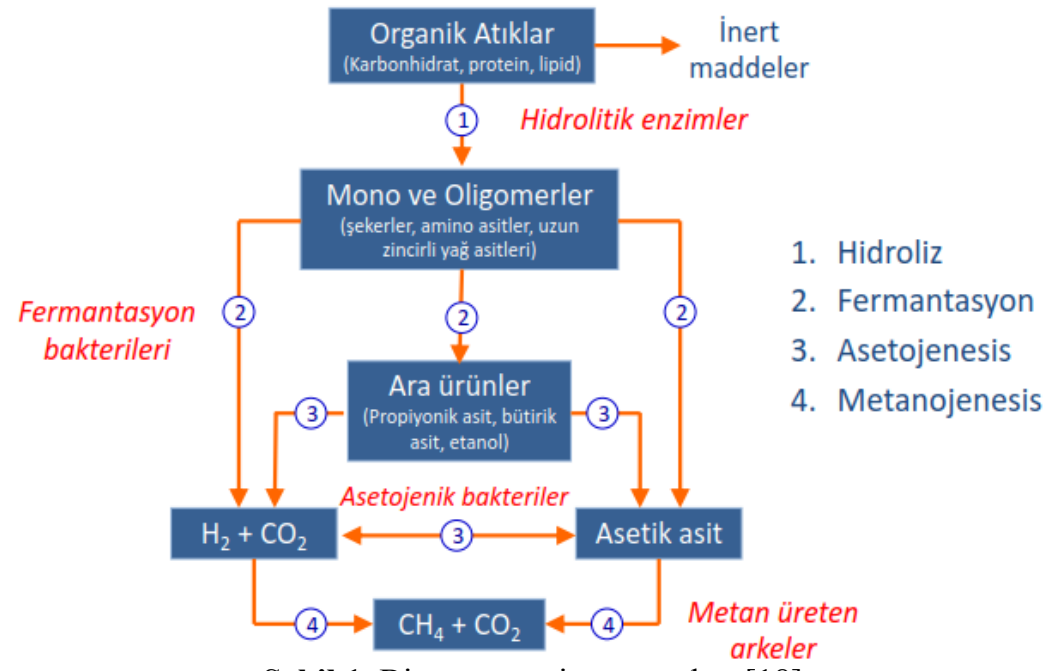

Şekil 1. Biyogaz üretim aşamaları [18]

Genellikle komplek organik polimerlerden oluşun biyokütle, Hidroliz aşamasında hidrolik ve fermantatif bakteri tarafindan kompleks ve uzun zincirli organik maddeler basit yapıdaki uçucu organik maddelere parçalanır. Bu aşamada oluşan yağ, protein ve karbonhidrat gibi polimerler anaerobik bakteriler tarafından daha küçük yapıdaki monomerlere dönüştürülür. İkinci aşamada, anaerobik bakteriler tarafindan bu monomerler kısa zincirli asitlere, karbondioksit, hidrojen ve alkollere dönüştürürler. Üçüncü aşamada ise asetojenik bakteriler hidrojen, asetat ve karbondioksit üretirler. Metenojenik mikroorganizmalar hidrokarbonu, asetatı ve hidrojeni kulanarak, asetojenik bakterileri olumsuz etkileyen hidrojeni ortamda uzaklaştırırlar. Son aşamada, asetojenik bakterileri ürettiği organik asitler, asetat ve hidrojen; metanojen mikroorganizmalar tarafından karbondioksit ile hidrojenin sentezlenmesi ve asetik asitin parçalanması ile metan ve karbon dioksite dönüştürmeleri sonucu biyogaz elde edilir. Biyogaz üretiminin \%27-30'u, asetik asitin oksidasyonu ile $\% 70$ 'i ise hidrojen ve karbondioksitin indirgenmesi ile üretilir $[17,19,20]$.

Biyogaz üretimini etkileyen en önemli etkenler; atığın kompozisyonu, $\mathrm{C} / \mathrm{N}$ oranı, $\mathrm{pH}$ değeri ve biyogaz reaktörünün sıcaklığıdır. Organik atıklar; karbonhidratlar, lipidler, proteinler ve lignoselülozdan oluşurlar. Karbonhidratlar; lipitler, proteinler ve selüloza göre daha hılı ve daha kolay fermente olurlarken, lipitlerin biyogaz potansiyeli karbonhidrat ve proteinlere göre daha fazladır [18].

Organik atıkları carbon ve azot oranı $(\mathrm{C} / \mathrm{N})$ biyogaz üretimini etkileyen önemli faktörlerden biridir. Biyogaz oluşumu için karbon gerekli iken, anaerobik bakterilerin gelişimi içinde azot gereklidir. Azotun azlığı bakteri gelişimini yavaşlatmakta ancak fazlalığı ise kötü kokulu ve yanmayan bir gaz olan $\mathrm{NH}_{3}$ oluşmasına neden olmaktadır. Bu nedenle ideal bir anaerobik çürütme için $\mathrm{C} / \mathrm{N}$ oranı $25-30 / 1$ oranında olması uygundur [21].

Ayrıca, $\mathrm{pH}$ değeri de biyogaz üretiminde etkilidir. Metan üreten bakterilerden, asit üreten bakteriler daha hızlı çoğaldıklarından sürekli biyogaz reaktörünün $\mathrm{pH}$ değeri kontrol edilmelidir. Uygun pH değeri 6,8 ile 7,5 arasında olmalıdır. [17,22].

Metan üreten bakteriler ani ve gece-gündüz sıcaklık değişiminden olumsuz yönde etkilenirler. Biyogaz üretimi ve hızı biyogaz üretim reaktörünün sıcaklığına bağlıdır. Anaerobik fermantasyon işleminde bekletme süresi atık maddelerin türüne, içerdikleri iyonlara, $\mathrm{pH}$ değerine ve bunlara bağımlı olarak oluşan mikroorganizmaların yapısına bağlı olarak 3 değişik sıcaklık bölgesi mevcuttur. Bunlar; 2 ile $20^{\circ} \mathrm{C}$ sicaklıklar arasinda 100 ile 300 gün 
bekleme süresi olan Psikofilik fermantasyon, 20 ile $40{ }^{\circ} \mathrm{C}$ sicaklıklar arasında 20 ile 40 gün bekleme süresi olan Mezofilik fermantasyon ve 40 ile $70{ }^{\circ} \mathrm{C}$ sıcaklıklar arasında çürüme hızı daha yüksek ve

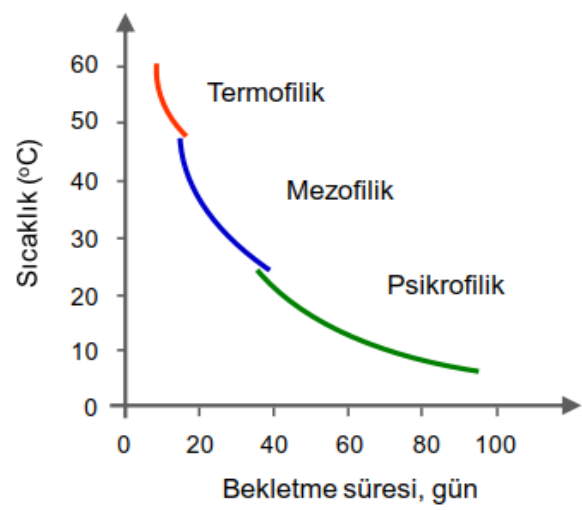

Şekil 2. Reaktör sıcaklığı ve bekleme süreleri [18]

\section{HAYVAN GÜBRESINDEN BIYYOGAZ ELDESI}

Tüm dünyada ve Türkiye'de hayvan kaynaklı atıklar önemli miktarda çevresel problemler oluşturmaktadır. Hayvansal atıkların herhangi işleme tabii tutulmadan doğrudan tarım alanlarına verilmesi mahsul kalitesini ve toprak yapısının faydalı kullanım özelliklerini bozmaktadır. Ayrıca atıkların uygun olmayan şartlarda depolanmasında, sinek, haşere, kötü koku gibi olumsuzlukların yanı sira yeraltı sularının kirlenmesine sebep olmaktadır [23].

Her türlü çiftlik hayvanı kaynaklı atıklardan biyogaz üretimi mümkün olmaktadır. Ancak dünyada en yaygın olanları; sığır, koyun, keçi, domuz ve kümes hayvanlarıdır. Bunun yanı sıra at ve diğer tek tırnaklı hayvan gübreleri de içerdikleri katı madde miktarı yönünden biyogaz üretimi için oldukça uygundur [24].

Keçi ve koyun gübreleri, benzer kimyasal karakteristik özelliklerindeki kümes ve domuz gübreleriyle karıştırıldığında anaerobik çürüme süresi uzamakta ve biyogaz üretimi daha az gerçekleşmektedir. Keçi ve koyun gübrelerinin, sığır gübresiyle karıştırılması sonucu biyogaz üretimi daha verimli olmaktadır [25].
Sıcaklık arttıkça;

Reaksiyon hızı artar, bekletme

süresi kısalır

Gerekli reaktör hacmi azalır

Organik maddelerin hidrolizi

hızlanır

bekleme süresi daha kısa olan Termofilik Fermantasyondur [16]. Şekil 2'de reaktör sıcaklığı ve bekleme süreleri verilmiştir.

Kümes hayvanların gübresi diğer hayvan gübrelerine oranla daha fazla biyoparçalanabilen organik madde içerirler. Kümes hayvanlarının yaş gübre üretimi günlük tavuk başına $0,08-0,125 \mathrm{~kg}$ arasında olup bununda yaklaşık \%20-25 kadarı katı madde içerir. Bu katı maddenin \%55-65 kadarı ise uçucu katı maddedir. Bu da kümes hayvanlarının gübresinin önemli bir biyogaz kaynağı olduğunu göstermektedir. Fakat tavuk gübresinin azot içeriği çok yüksek olması, biyogaz oluşumunu sırasında amonyak birikimine sebep olduğundan, oluşan amonyak biyogaz oluşum performansında bir azalmaya sebebiyet vermektedir [17].

Dünyada en çok biyogaz üretiminde büyük baş hayvanlarının gübresi kullanılmaktadır. Bunun başlıca nedenlerinden en önemlisi diğer hayvanlara göre günlük gübre miktarlarının fazla olmasıdır. Büyük baş hayvanlarından da et sığırlarının gübrelerindeki katı madde oranı süt sığırlarına göre daha yüksektir. Süt sığırlarının gübrelerindeki su ve lif içerikleri yüksek olması ve lif yüksek düzeyde çürümeye dirençli olduğundan daha düşük oranda metan gazı elde edilir [26].

Bu çalışmada Türkiye'deki hayvancılık sektöründe kabul edilen günlük atık miktarları ve özellikleri göz önüne alınmıştır. Hayvan türüne bağlı günlük 
gübre miktarları birim hayvan başına yaş gübre oluşumu (kg/gün-hayvan), Katı madde oranı (KM), uçucu katı madde oranı (UKM), Katı madde içerisindeki uçucu katı madde oranı ve uçucu katı maddeden üretilen metan oranı Çizelge 2'de verilmiştir.

Çizelge 2. Hayvan türüne göre biyogaz prosesi için kabul edilen gübre miktarı ve özellikleri [27]

\begin{tabular}{|c|c|c|c|c|c|}
\hline Hayvan Türü & $\begin{array}{c}\text { Hayvan Başına } \\
\text { Ortalama } \\
\text { Günlük Gübre } \\
\text { Üretimi }\end{array}$ & $\begin{array}{l}\text { Katı } \\
\text { Madde } \\
\text { Oranı } \\
\text { (KM) }\end{array}$ & $\begin{array}{l}\text { Yaş Gübredeki } \\
\text { Uçucu Katı } \\
\text { Madde Oranı } \\
\text { (UKM) }\end{array}$ & $\begin{array}{c}\text { Katı Maddedeki } \\
\text { (KM) Uçucu Katı } \\
\text { Madde Oranı (UKM) }\end{array}$ & $\begin{array}{l}\text { Metan } \\
\text { Üretimi }\end{array}$ \\
\hline & kg/gün-hayvan & $\%$ & $\%$ & $\%$ & $\begin{array}{c}\mathrm{m}^{3} \mathrm{CH}_{4} / \mathrm{kg}- \\
\mathrm{UKM}\end{array}$ \\
\hline Süt Sı̆̆ırı & 43,00 & 13,95 & 11,63 & 83,36 & 0,18 \\
\hline Et sı̆̆ırı & 29,00 & 14,66 & 12,41 & 84,65 & 0,33 \\
\hline $\begin{array}{l}\text { Buzağ1 (Genç } \\
\text { Yavru) }\end{array}$ & 2,48 & 8,39 & 3,71 & 44,23 & 0,33 \\
\hline Koyun & 2,40 & 27,50 & 23,00 & 83,63 & 0,30 \\
\hline Keçi & 2,05 & 31,71 & 23,17 & 73,06 & 0,30 \\
\hline At & 20,40 & 29,41 & 19,61 & 66,67 & 0,30 \\
\hline Et tavuğu & 0,19 & 25,88 & 20,00 & 77,278 & 0,35 \\
\hline Yumurta tavuğu & 0,13 & 25,00 & 18,75 & 75,00 & 0,35 \\
\hline Hindi & 0,38 & 25,53 & 19,36 & 75,83 & 0,35 \\
\hline Ördek ve kaz & 0,33 & 28,18 & 17,27 & 61,28 & 0,35 \\
\hline
\end{tabular}

Canlı türlerine göre biyogaz üretim miktarları ile gübrenin su ile seyretme oranları Çizelge 3'de verilmiştir.

Çizelge 3. Hayvan cinsine bağlı olarak biyogaz üretimi ve seyreltme oranı [16]

\begin{tabular}{|l|c|c|c|}
\hline $\begin{array}{l}\text { Hayvan } \\
\text { Türüi }\end{array}$ & $\begin{array}{c}\text { Nem } \\
\text { Miktarı }\end{array}$ & $\begin{array}{c}\text { Biyogaz } \\
\text { Üretimi }\end{array}$ & $\begin{array}{c}\text { Seyreltme } \\
\text { Oranı } \\
\text { (Gübre/Su) }\end{array}$ \\
\hline Bazda & lt/kg & - \\
\hline Sığır & $80-85$ & 40 & $1 / 1$ \\
\hline Domuz & $75-85$ & 70 & $1 / 2$ \\
\hline $\begin{array}{l}\text { Kümes } \\
\text { Hayvanı }\end{array}$ & $70-80$ & 60 & $1 / 3$ \\
\hline Keçi & $75-80$ & 60 & $2 / 3$ \\
\hline Koyun & $75-80$ & 50 & $2 / 3$ \\
\hline At & $80-85$ & 50 & $2 / 3$ \\
\hline
\end{tabular}

\section{MATERYAL VE METOT}

\subsection{Materyal}

\subsubsection{Adana İli Biyogaz Potansiyeli ve Mevcut Durum}

Üretimi tüketiminden hızlı olan biyokütle enerjisinin önemi gün geçtikçe artmaktadır. Biyokütle enerjisi, hayvansal atık ve atıkların kaynaksal olarak kullanılması ile yapılan biyolojik fermente sonucu oluşan bir enerji çeşididir. Adana ili gerek tarım gerekse hayvancılık yönünden Türkiye'nin en önemli şehirlerinden birisi olup Türkiye de hayvan yetiştiriciliği yapılan iller arasında BEPA tarafindan yapılan sıralamada 2. en fazla yetiştiricilik yapan iller grubu içerisinde yer almaktadır [28]. Mevcut durumda Adana ili bölgesinde 4 adet kurulu biyogaz tesisi 
bulunmaktadır. Bunlardan ikisi Adana Büyükşehir Belediyesinin kurmuş olduğu atık su santralleri olup ve bu kurulu santrallerin kapasiteleri Çizelge 4'de görülmektedir.

Adana bölgesinde yer alan Sofulu Çöplüğü Biyogaz tesisi toplam 15,57 MWe kurulu gücü ile
Türkiye'de 564. sırada yer alırken Adana'nın da 24. büyük güç santrali konumundadır. Türkiye'nin 5 . Büyük biyogaz üretim tesisi konumunda bulunan Sofulu, ortalama 88.752,39 MWh elektrik üretimi kapasitesi ile günde yaklaşık 26.813 kişinin ihtiyaç duyduğu günlük tüm enerji ihtiyacını karşılamaktadır.

Çizelge 4. Adana da kurulu biyogaz tesisleri [29]

\begin{tabular}{|l|c|c|c|}
\hline Santral Adı & İl & Firma & Üretilen Güç \\
\hline Adana Batı Atıksu Biyogaz Santrali & Adana & Adana Büyükşehir Belediyesi & $0,80 \mathrm{MW}$ \\
\hline Adana Doğu Atıksu Biyogaz Santrali & Adana & Adana Büyükşehir Belediyesi & $0,80 \mathrm{MW}$ \\
\hline Pakmil Biyokütle Santrali & Adana & Pakmil Enerji & $1,76 \mathrm{MW}$ \\
\hline Sofulu Çöplüğü Biyogaz Santrali & Adana & ITC Katı Atık Enerji & $16 \mathrm{MW}$ \\
\hline
\end{tabular}

$\mathrm{Bu}$ üretim ortalama konut tüketimi dikkate alındığında yaklaşık 28.175 konutun enerji ihtiyacına denk gelmektedir. Sofulu çöplüğü biyogaz santrali güç üretiminin Adana ili elektrik tüketimine oranı incelendiğinde, tesisin Adana ilinin 2015 yılındaki enerji ihtiyacının \%1'ne karşıladığ1 görülmektedir. Bu oranın Türkiye'nin enerji tüketiminin \%0,028'ine karşılık gelmektedir. Buda tesisin ülke ekonomisine katkısını net olarak göstermektedir [30].

\subsubsection{Adana İli Hayvansal Gübre Yönünden Biyogaz Potansiyeli}

Bu çalışmada Adana'daki hayvansal gübrelerden metan cinsinden biyogaz potansiyeli ve elde edilen metanın enerji değeri hesap edilmiştir. Adana ili sahip olduğu hayvan sayısı bakımından BEPA tarafindan yapılan sıralamada en yüksek hayvan sayısına sahip iller kategorisinde yer almaktadır [28]. Böylesi büyük hayvan sayısına sahip olan Adana ilinin biyogaz potansiyeli de göz ard1 edilemeyecek kadar büyüktür. Türkiye İstatistiki Bölge Birimleri Sınıflandırması (Türkiye İBBS) Avrupa Birliği ülkelerinin kullandığı İstatistiki Bölge Birimleri Sınıflandırması içinde Türkiye için kullanılan sınıflandırma olup, üç ayrı düzeyde İBBS bölgesi vardır. Bunlardan; Türkiye İstatistik Kurumu'nda (TUIK) Düzey-3 olarak nitelendirilen Türkiye İBBS3 (İl Düzeyi) olarak geçen sınıflandırma kullanılmıştır. TUİK verilerinden elde edilen Adana ili 2015-2018 y1llarına ait hayvan türüne göre hayvan sayıları verileri Çizelge 5'de görülmektedir.

Çizelge 5. Adana İli 2015-2018 y1llarına ait hayvan türüne göre hayvan sayıları [31]

\begin{tabular}{|l|r|r|r|r|}
\hline \multirow{2}{*}{ Hayvan Türü } & \multicolumn{3}{|c|}{ Yllara Göre Hayvan Sayısı (Adet) } \\
\cline { 2 - 5 } & $\mathbf{2 0 1 5}$ & $\mathbf{2 0 1 6}$ & $\mathbf{2 0 1 7}$ & $\mathbf{2 0 1 8}$ \\
\hline Kültür ve melez Süt sığır (Yetişkin) & 123.256 & 125.402 & 129.057 & 143.356 \\
\hline Kültür ve melez Et sığır (Yetişkin) & 44.824 & 45.309 & 40.187 & 52.929 \\
\hline Yerli sı̆̆ır & 4.194 & 2.733 & 2.685 & 2.761 \\
\hline Genç Yavru (Buzağı) & 38.399 & 42.914 & 63.212 & 66.384 \\
\hline Koyun & 287.379 & 267.400 & 358.918 & 380.209 \\
\hline Keçi & 372.328 & 370.880 & 417.131 & 427.691 \\
\hline At-Katır-Eşek & 3.639 & 3.561 & 2.835 & 2.643 \\
\hline Et tavuğu & 583.385 & 575.991 & 1.006 .623 & 1.052 .592 \\
\hline Yumurta Tavuğu & 725.267 & 756.988 & 860.515 & 920.694 \\
\hline Hindi & 2.510 & 2.889 & 2.310 & 2.592 \\
\hline Kaz & 2.837 & 3.044 & 3.029 & 8.921 \\
\hline Ördek & 2.477 & 2.505 & 2.065 & 2.220 \\
\hline Toplam & $\mathbf{2 . 1 9 0 . 4 9 5}$ & $\mathbf{2 . 1 9 9 . 6 1 6}$ & $\mathbf{2 . 8 8 8 . 5 6 7}$ & $\mathbf{3 . 0 6 2 . 9 9 2}$ \\
\hline
\end{tabular}


Bir yılda 6 dönem etlik piliç yetiştirilmektedir. 40-42 gün yetiştirme süresi, 18-20 gün ise kümes temizliği, dezenfeksiyonu ve kümesin dinlendirilme süresi için gerekli olan süreler olup toplam 60 gün yani 2 ay gereklidir. Her iki ayda bir piliç yetiştirildiğinde yılda $6 \mathrm{kez}$ yetiştirme yapılmaktadır. $\mathrm{Bu}$ nedenle TÜİK'ten alınan et tavuğu sayısı 6' bölünerek alınmıştır.
TÜİK 2018 yılı verilerine göre, Adana'da toplamda 265.430 adet büyükbaş, 2.643 Tek tırnaklı, 807.900 adet küçükbaş, 1.987.019 adet kanatlı olmak üzere 3.062.992 adet hayvan bulunmaktadir. Bu bağlamda, var olan hayvanların atık gübre miktarı incelenmiştir. Çizelge 2 ve Çizelge 5'de verilen değerler göre hesaplanan 2018 yılına ait Adana İli hayvansal atık miktarı Çizelge 6'da verilmektedir.

Çizelge 6. Adana İli 2018 yılı hayvansal atık miktarı

\begin{tabular}{|l|c|c|c|c|}
\hline \multirow{2}{*}{ Hayvan Türü } & $\begin{array}{c}\mathbf{2 0 1 8} \text { Yılı } \\
\text { Hayvan Sayısı }\end{array}$ & $\begin{array}{c}\text { Günlük } \\
\text { Gübre } \\
\text { Üretimi }\end{array}$ & $\begin{array}{c}\text { Yıllık Gübre } \\
\text { Üretimi }\end{array}$ & $\begin{array}{c}\text { Toplam Hayvan } \\
\text { Gübre Miktarına } \\
\text { Oranı }\end{array}$ \\
\cline { 2 - 5 } & adet & ton/gün & ton/yıl & \% \\
\hline $\begin{array}{l}\text { Kültür ve melez } \\
\text { Süt sı̆̆ır (Yetişkin) }\end{array}$ & 143.356 & $6.164,308$ & $2.249 .972,420$ & 60,960 \\
\hline $\begin{array}{l}\text { Kültür ve melez Et } \\
\text { sığır (Yetişkin) }\end{array}$ & 52.929 & $1.534,941$ & $560.253,465$ & 15,179 \\
\hline Yerli sığır & 2.761 & 80,069 & $29.225,185$ & 0,792 \\
\hline $\begin{array}{l}\text { Genç Yavru } \\
\text { (Buzağı) }\end{array}$ & 66.384 & 164,632 & $60.090,797$ & 1,628 \\
\hline Koyun & 380.209 & 912,502 & $333.063,084$ & 9,024 \\
\hline Keçi & 427.691 & 876,767 & $320.019,791$ & 8,671 \\
\hline At-Katır-Eşek & 2.643 & 53,917 & $19.679,778$ & 0,533 \\
\hline Et tavuğu & 1.052 .592 & 199,999 & $72.997,255$ & 1,978 \\
\hline Yumurta Tavuğu & 920.694 & 119,690 & $43.686,930$ & 1,184 \\
\hline Hindi & 2.592 & 0,985 & 359,510 & 0,010 \\
\hline Kaz & 8.921 & 3,390 & $1.237,343$ & 0,034 \\
\hline Ördek & 2.220 & 0,844 & 307,914 & 0,008 \\
\hline Toplam & $\mathbf{3 . 0 6 2 . 9 9 2}$ & $\mathbf{1 0 . 1 1 2 , 0 4}$ & $\mathbf{3 . 6 9 0 . 8 9 3 , 4 7}$ & $\mathbf{1 0 0 , 0 0 0}$ \\
\hline
\end{tabular}

Adana genelinde 2018 y1lı itibariyle, toplamda 3.690.893,47 ton/yıl hayvan gübresi üretilmektedir. $\mathrm{Bu}$ miktarın 2.919.221,645 ton/yıl'ını büyükbaş, 653.082,875ton/yıl'ın1 küçükbaş ve $118.588,952$ ton/y1l'ını ise kanatlı hayvan gübreleri oluşturmaktadır. Elde edilen bu değerler baz alınarak üretilebilecek enerji miktarı hesaplanmıştır.

\subsection{Yöntem}

Adana iline ait toplam gübre miktarı Çizelge 6 ile verilmiştir. Ancak burada verilen gübre oluşum miktarları potansiyel gübre üretimi olup pratikte bu gübrenin sadece belirli bir kısmı toplanabilmektedir. Hayvansal gübrelerin toplanabilirliği, hayvanların kapalı alanda bulunma süreleri ile, kapalı mekanlarda oluşan atıkların toplama ve biriktirme imkanlarıyla ilişkilidir. Örneğin Türkiye'nin batı bölgeleri, doğu bölgeleri ile karşılaştırıldığında daha büyük işletmelere sahiptirler. Genellikle kültür ve melez ırk süt ve et sığırları ahırlarda tutulmaktadır. Bazı kırsal bölgelerde yerli ırk büyük baş hayvanlar çayır ve meralarda otlatılmaktadır.

Türkiye'de hayvan gübresinden biyogaz üretim potansiyeli ile ilgili yapılan çalışmalarda, toplanabilir faydalı gübre miktarı teknik biyogaz potansiyeli olarak tanımlanmıştır. $\mathrm{Bu}$ çalışmada 
hayvan türüne bağlı olarak, hayvanların kapalı hesap edilmesinde kabul edilen değerler ortamda kalma süreleri ile biyogaz potansiyelinin Çizelge 7'de verilmiştir.

Çizelge 7. Bu çalışmada hayvan türüne bağlı olarak, hayvanların kapalı ortamda kalma süreleri ile biyogaz potansiyelinin hesap edilmesinde kabul edilen değerler [17,32,33]

\begin{tabular}{|c|c|c|c|c|c|}
\hline \multirow[t]{2}{*}{ Hayvan Türü } & $\begin{array}{c}\text { Hayvan Başına } \\
\text { Ortalama Günlük } \\
\text { Yaş Gübre } \\
\text { Üretimi }\left(\mathrm{M}_{\mathrm{YG}}\right) \\
\end{array}$ & $\begin{array}{l}\text { Toplanabilir } \\
\text { Faydalı Gübre } \\
\text { Oranı (T) }\end{array}$ & $\begin{array}{l}\text { Yaş Gübredeki } \\
\text { Katı Madde } \\
\text { Oranı (KM) }\end{array}$ & $\begin{array}{l}\text { KM İçerisindeki } \\
\text { Uçucu Katı } \\
\text { Madde Oranı } \\
\text { (UKM) }\end{array}$ & $\begin{array}{l}\text { Metan Üretimi } \\
\text { (MO) }\end{array}$ \\
\hline & kg/gün-hayvan & $\%$ & $\%$ & $\%$ & $\begin{array}{c}\mathrm{Nm}^{3} \mathrm{CH}_{4} / \mathrm{kg}- \\
\text { UKM }\end{array}$ \\
\hline $\begin{array}{l}\text { Kültür ve } \\
\text { melez Süt sığır } \\
\text { (Yetişkin) }\end{array}$ & 43,00 & 100 & 17,27 & 83,36 & 0,18 \\
\hline $\begin{array}{l}\text { Kültür ve } \\
\text { melez Et sı̆̆ır } \\
\text { (Yetișkin) }\end{array}$ & 29,00 & 100 & 12,41 & 84,65 & 0,33 \\
\hline Yerli sı̆̆ır & 29,00 & 50 & 17,27 & 83,36 & 0,33 \\
\hline $\begin{array}{l}\text { Genç Yavru } \\
\text { (Buzağ1) }\end{array}$ & 2,48 & 100 & 3,71 & 44,23 & 0,33 \\
\hline Koyun & 2,40 & 13 & 23,00 & 83,63 & 0,30 \\
\hline Keçi & 2,05 & 13 & 23,17 & 73,06 & 0,30 \\
\hline At-Katır-Eşek & 20,40 & 29 & 19,61 & 66,67 & 0,30 \\
\hline Et tavuğu & 0,19 & 66 & 20,00 & 77,278 & 0,35 \\
\hline $\begin{array}{l}\text { Yumurta } \\
\text { Tavuğu }\end{array}$ & 0,13 & 99 & 18,75 & 75,00 & 0,35 \\
\hline Hindi & 0,38 & 68 & 19,36 & 75,83 & 0,35 \\
\hline Kaz & 0,33 & 68 & 17,27 & 61,28 & 0,35 \\
\hline Ördek & 0,33 & 68 & 17,27 & 61,28 & 0,35 \\
\hline
\end{tabular}

Biyogaz potansiyelini hesaplamak içim aşağıdaki denklemler kullanılarak hesap edilmiştir. Hayvanlar tarafından yıllık olarak üretilebilecek toplam yaş gübre miktarı; (Eşitlik 1)

$\mathrm{M}_{\mathrm{YYM}}=\mathrm{M}_{\mathrm{YG}} * \mathrm{~S} * 365$

Burada, $\mathrm{M}_{\mathrm{YYM}}$; Hayvanlar tarafindan bir yilda üretilebilecek toplam gübre miktar $(\mathrm{kg} / \mathrm{yl} 1), \mathrm{M}_{\mathrm{YG}}$ bir hayvanın bir yılda üretebileceği gübre miktarı (kg/yıl-hayvan) ve $\mathrm{S}$ ise hayvan sayısıdır. Hayvanların barınakta kalma süreleri göz önüne alındığında yıllık toplam faydalanılabilir yaş gübre miktarı; (Eşitlik 2)

$\mathrm{M}_{\mathrm{YFYG}}=\mathrm{M}_{\mathrm{YYM}} * \mathrm{~T}$

Burada, $\mathrm{M}_{\mathrm{YFYG}}$ hayvanlar tarafindan üretilen yıllık toplanabilir faydalı toplam yaş gübre miktarı $(\mathrm{kg} / \mathrm{y} 1 \mathrm{l})$ ve $\mathrm{T}$ toplanabilir faydalı gübre oranı $(\%)$.
Üretilen yaş gübre içerisindeki katı madde miktarı; (Eşitlik 3)

$\mathrm{M}_{\mathrm{KM}}=\mathrm{M}_{\mathrm{YFYG}} * \mathrm{KM}$

Burada, $\mathrm{M}_{\mathrm{KM}}$ Hayvanlar tarafindan üretilen yıllık toplanabilir faydalı gübre içerisindeki toplam katı madde miktarı (kg/yıl), KM ise yaş gübre içerisindeki katı madde oranı (\%). Katı madde içerisindeki uçucu katı madde miktarı; (Eşitlik 4)

$\mathrm{M}_{\mathrm{UKM}}=\mathrm{M}_{\mathrm{KM}} * \mathrm{UKM}$

Burada, $M_{U K M}$ hayvanlar tarafından üretilen yaş gübre içerisindeki yıllık toplam uçucu katı madde miktarı (kg/yıl), UKM ise katı madde miktarı içerisindeki uçucu katı madde oranı (\%) (Eşitlik 5)

$\mathrm{M}_{\text {METAN }}=\mathrm{M}_{\mathrm{UKM}} * \mathrm{MO}$ 
$\mathrm{M}_{\text {METAN }}$ hayvanlar tarafindan üretilen toplanabilir faydalı gübreden elde edilebilecek toplam yıllık metan miktarı $\left(\mathrm{m}^{3} \mathrm{CH}_{4} / \mathrm{y} 1 \mathrm{l}\right)$, MO $1 \mathrm{~kg}$ UKM'den üretilen metan miktarıdır. \%60 metan içeriğine sahip biyogazın enerji değerinin $22,7 \mathrm{MJ} / \mathrm{Nm}^{3}$ ve buna bağlı olarak metan gazının enerji değeri $36 \mathrm{MJ} / \mathrm{Nm}^{3}$ olarak alınarak hayvanlardan üretilen yıllık toplam biyogazın enerji miktarı hesaplanabilmektedir [17]. Metan gazından üretilebilecek enerji; (Eşitlik 6)

$\mathrm{Q}=\mathrm{M}_{\text {METAN }} * \mathrm{H}_{\text {METAN }}$

Burada, Q bir yılda üretilecek metanın enerji karşılığ1 $(\mathrm{MJ} / \mathrm{y} 1 \mathrm{l})$ ve $\mathrm{H}_{\text {METAN }}$ metan gazının 1sıl değeri olup $36 \mathrm{MJ} / \mathrm{m}^{3}$ olarak alınmıştır. Metan gazı bir CHP motorunda yakılarak elektrik üretilmesi sonucu elde edilecek elektrik miktarı; (Eşitlik 7)

$\mathrm{E}=\mathrm{M}_{\mathrm{METAN}} * \eta_{\mathrm{e}} * \mathrm{~W}$

Burada, E CHP motorunun yıllık elektrik üretimi (MWhe/yil), $\eta_{\mathrm{e}}$ CHP motorunun elektriksel verimi (\%35 alınmıştır) ve W Metan gazının kWh olarak enerji değeri olup $10 \mathrm{kWh} / \mathrm{m}^{3}$ olarak alınmıştır.

\section{ARAȘTIRMA VE BULGULAR}

Adana İli mevsimsel olarak sicak iklime sahip olduğundan kurulacak olan biyogaz tesisi için yılın birçok ayında 1sıtma ihtiyacı hiç olmadan veya bazı aylar az miktarda 1sıtma gerekeceğinden üretilen biyogazın tamamı enerji kaynağı olarak değerlendirilebilir. Adana İli'nde hayvan türüne bağlı olarak, TÜİK verilerine göre hayvan sayıları Çizelge 5'de verilmiştir. Buradan görüldüğü gibi toplam hayvan sayısı 2015 yılın 2.190.495 iken 2018 yılında 3.062.992 adete yükselmiştir. Yerli sığır ve tek tırnaklı hayvan sayısında azalma gözlenmesine rağmen diğer hayvan türlerinde büyük bir artış olmuştur.

Tüm bu verilerden de anlaşılacağı üzere Adana İli hayvan yetiştiriciliği yönünden Türkiye' önemli bölgelerden biridir. Bu nedenle hayvan gübresinden biyogaz üretimi potansiyeli yüksek illerimizdendir. Adana ilinde yetiştirilen hayvan türüne göre hayvan sayısı, yıllık toplanabilir faydalı gübre miktarı, katı madde (KM) miktarı ve uçucu katı madde (UKM) miktarları Çizelge 8'de verilmiştir.

Çizelge 8. Adana ili 2018 yılı hayvan türüne göre üretilen toplanabilir faydalı gübre, KM miktarı ve UKM miktarı

\begin{tabular}{|l|c|c|c|c|c|c|}
\hline \multirow{2}{*}{ Hayvan Türü } & $\begin{array}{c}\mathbf{2 0 1 8} \text { Yılı } \\
\text { Hayvan } \\
\text { Sayısı }\end{array}$ & $\begin{array}{c}\text { Toplanabilir } \\
\text { Faydalı Gübre } \\
\text { Miktarı }\end{array}$ & $\begin{array}{c}\text { Katı Madde } \\
\text { Miktarı } \\
\text { (KM) }\end{array}$ & $\begin{array}{c}\text { Gübre } \\
\text { Içerisindeki } \\
\text { KM Oranı }\end{array}$ & $\begin{array}{c}\text { Uçucu Katı } \\
\text { Madde } \\
\text { Miktarı } \\
\text { (UKM) }\end{array}$ & $\begin{array}{c}\text { Gübre } \\
\text { Içerisindeki } \\
\text { UKM Oranı }\end{array}$ \\
\cline { 2 - 7 } & adet & ton/yıl & ton/yıl & $\%$ & ton/y1l & $\%$ \\
\hline $\begin{array}{l}\text { Kültür ve melez } \\
\text { Süt sığır (Yetişkin) }\end{array}$ & 143.356 & $2.249 .972,420$ & $388.570,237$ & 77,475 & $323.912,15$ & 77,929 \\
\hline $\begin{array}{l}\text { Kültür ve melez Et } \\
\text { sığır (Yetişkin) }\end{array}$ & 52.929 & $560.253,465$ & $69.527,455$ & 13,862 & $58.854,99$ & 14,160 \\
\hline Yerli sığır & 2.761 & $14.612,593$ & $2.523,595$ & 0,503 & $2.103,67$ & 0,506 \\
\hline $\begin{array}{l}\text { Genç Yavru } \\
\text { (Buzağı) }\end{array}$ & 66.384 & $60.090,797$ & $2.229,369$ & 0,444 & 986,05 & 0,237 \\
\hline Koyun & 380.209 & $43.298,201$ & $9.958,586$ & 1,985 & $8.328,37$ & 2,004 \\
\hline Keçi & 427.691 & $41.602,573$ & $9.639,316$ & 1,921 & $7.042,48$ & 1,694 \\
\hline At-Katır-Eşek & 2.643 & $5.707,136$ & $1.119,169$ & 0,223 & 746,15 & 0,180 \\
\hline Et tavuğu & 1.052 .596 & $48.178,188$ & $9.635,638$ & 1,921 & $7.446,23$ & 1,791 \\
\hline Yumurta Tavuğu & 920.694 & $43.250,061$ & $8.109,386$ & 1,616 & $6.082,04$ & 1,463 \\
\hline Hindi & 2.592 & 244,467 & 47,329 & 0,009 & 35,89 & 0,009 \\
\hline Kaz & 8.921 & 841,393 & 145,309 & 0,028 & 89,05 & 0,021 \\
\hline Ördek & 2.220 & 209,382 & 36,160 & 0,007 & 22,16 & 0,005 \\
\hline Toplam & $\mathbf{3 . 0 6 2 . 9 9 2}$ & $\mathbf{3 . 0 6 8 . 2 6 0 , 6 7}$ & $\mathbf{5 0 1 . 5 4 1 , 5 4 9}$ & $\mathbf{1 0 0 , 0 0 0}$ & $\mathbf{4 1 5 . 6 4 9 , 2 2}$ & $\mathbf{1 0 0 , 0 0}$ \\
\hline
\end{tabular}


Adana İli'nde büyük baş hayvan olarak en fazla 143.356 adetle olarak sığırı besiciliği yapılmaktadır. Et tavukçuluğu 1.052.592 adet ve yumurta tavukçuluğu 920.694 adet ile Türkiye'de önemli merkezlerden biri olduğu görülmektedir. Toplanabilir faydalı gübre yılda 3.068.260,67 ton olup büyük bir biyogaz üretim potansiyeli sahiptir. Çizelge 9'da Adana İli'nde bulunan hayvan türüne göre toplanabilir faydalı gübrelerden üretilebilecek metan gazı, enerji değeri ve elektrik üretim potansiyeli verilmiştir.

Çizelge 9. Adana İli'nin hayvan türüne bağlı olarak hayvan gübresinden metan, enerji ve elektrik üretilebilecek miktarları

\begin{tabular}{|l|c|c|c|c|c|}
\hline \multirow{2}{*}{ Hayvan Türü } & $\begin{array}{c}\mathbf{2 0 1 8} \text { Ylı Hayvan } \\
\text { Sayısı }\end{array}$ & $\begin{array}{c}\text { Metan } \\
\text { Üretimi }\end{array}$ & $\begin{array}{c}\text { Enerji } \\
\text { Değeri }\end{array}$ & $\begin{array}{c}\text { Enerji } \\
\text { Değeri }\end{array}$ & $\begin{array}{c}\text { Elektrik Enerjisi } \\
\text { Değeri }\end{array}$ \\
\cline { 2 - 6 } & adet & $\mathrm{m}^{3}-\mathrm{CH}_{4} / \mathrm{y} 1 \mathrm{l}$ & GJ/y1l & TEP/y1l & MWhe/yıl \\
\hline $\begin{array}{l}\text { Kültür ve melez süt } \\
\text { sığır (Yetişkin) }\end{array}$ & 143.356 & $58.304,19$ & $2.098,951$ & 50,130 & 204,065 \\
\hline $\begin{array}{l}\text { Kültür ve melez et sığır } \\
\text { (Yetişkin) }\end{array}$ & 52.929 & $19.422,15$ & 699,197 & 16,699 & 67,978 \\
\hline Yerli sığır & 2.761 & 694,21 & 24,992 & 0,597 & 2,430 \\
\hline Genç yavru (Buzağ1) & 66.384 & 325,40 & 11,714 & 0,280 & 1,139 \\
\hline Koyun & 380.209 & $2.498,51$ & 89,946 & 2,148 & 8,745 \\
\hline Keçi & 427.691 & $2.112,75$ & 76,059 & 1,817 & 7,395 \\
\hline At-katır-eşek & 2.643 & 223,85 & 8,058 & 0,192 & 0,783 \\
\hline Et tavuğu & 1.052 .596 & $2.606,18$ & 93,822 & 2,241 & 9,122 \\
\hline Yumurta tavuğu & 920.694 & $2.128,71$ & 76,634 & 1,830 & 7,451 \\
\hline Hindi & 2.592 & 12,56 & 0,452 & 0,011 & 0,044 \\
\hline Kaz & 8.921 & 31,17 & 1,122 & 0,027 & 0,109 \\
\hline Ördek & 2.220 & 7,76 & 0,279 & 0,007 & 0,027 \\
\hline Toplam & $\mathbf{3 . 0 6 2 . 9 9 2}$ & $\mathbf{8 8 . 3 6 7 , 4 1 7}$ & $\mathbf{3 . 1 8 1 , 2 2 7}$ & $\mathbf{7 5 , 9 7 9}$ & $\mathbf{3 0 9 , 2 8 6}$ \\
\hline
\end{tabular}

Toplam 3.062.992 adet hayvandan toplam y1lda $88.367,417 \mathrm{~m}^{3}$ metan üretilebileceği Çizelge 9'dan görülmektedir. $\mathrm{Bu}$ metan gazının $78.745,94 \mathrm{~m}^{3}$ toplam büyükbaş hayvanlardan, $4.611,26 \mathrm{~m}^{3}$ toplam küçükbaş hayvanlardan, $223,85 \mathrm{~m}^{3}$ toplam tek tırnaklı hayvanlardan ve $4.786,38 \mathrm{~m}^{3}$ toplam kanatlı hayvanlardan üretilebileceği hesaplanmıştır. 2018 yılında toplanabilir faydalı hayvan gübresinden biyogaz üretimi yapılması sonucu, üretilebilecek toplam metan gazının enerji değeri 3.181,227 GJ/y1 ve 75,979 TEP/yıl olacaktır. Metan gazı ortalama elektrik verimi \%35 olan bir CHP motorunda yakıldığında yılda 309,286 MWhe elektrik üretiminin mümkün olacağı görülmektedir. Buda, $1 \mathrm{kWh}$ elektrik tasarrufunun yaklaşı olarak $0,58 \mathrm{~kg}$ $\mathrm{CO}_{2}$ salınımına denk geldiği düşünüldüğünde hayvansal atıklardan biyogaz eldesi ile yılda yaklaşık 179,4 ton $\mathrm{CO}_{2}$ salınımının engellenebileceği anlamına gelmektedir [34].
Şekil 3'de 2018 yılındaki hayvan türüne bağlı olarak toplanabilir faydalı toplam hayvan gübrelerinin üretilebilecek UKM ve Metan oranları grafiksel olarak verilmiştir. Tüm yıl boyunca toplanabilir faydalı gübrelerde elde edilebilecek UKM ve Metan oranları incelendiğinde, toplam üretilen UKM ve Metan miktarları içerisinde $\% 77$ UKM ve \%53 Metan oranı ile en fazla kültür ve melez süt sığırlarından elde edilebileceği görülmektedir. Kültür ve melez süt sığırlarının sayısı ve et sığırlarına göre gübre içerisindeki katı madde oranları fazla olduğundan dolayı en fazla UKM oranı ve metan üretimi bunlardan üretilmektedir. Toplam UKM oranın \%77'sinin kültür ve melez süt sığırlarından üretilebileceği görülse de UKM den üretilebilecek metan üretimi $\% 18$ ile en düşük bu hayvanlar olduğundan Metan üretimi $\% 53$ oranında gerçekleşmesi söz konusudur. 

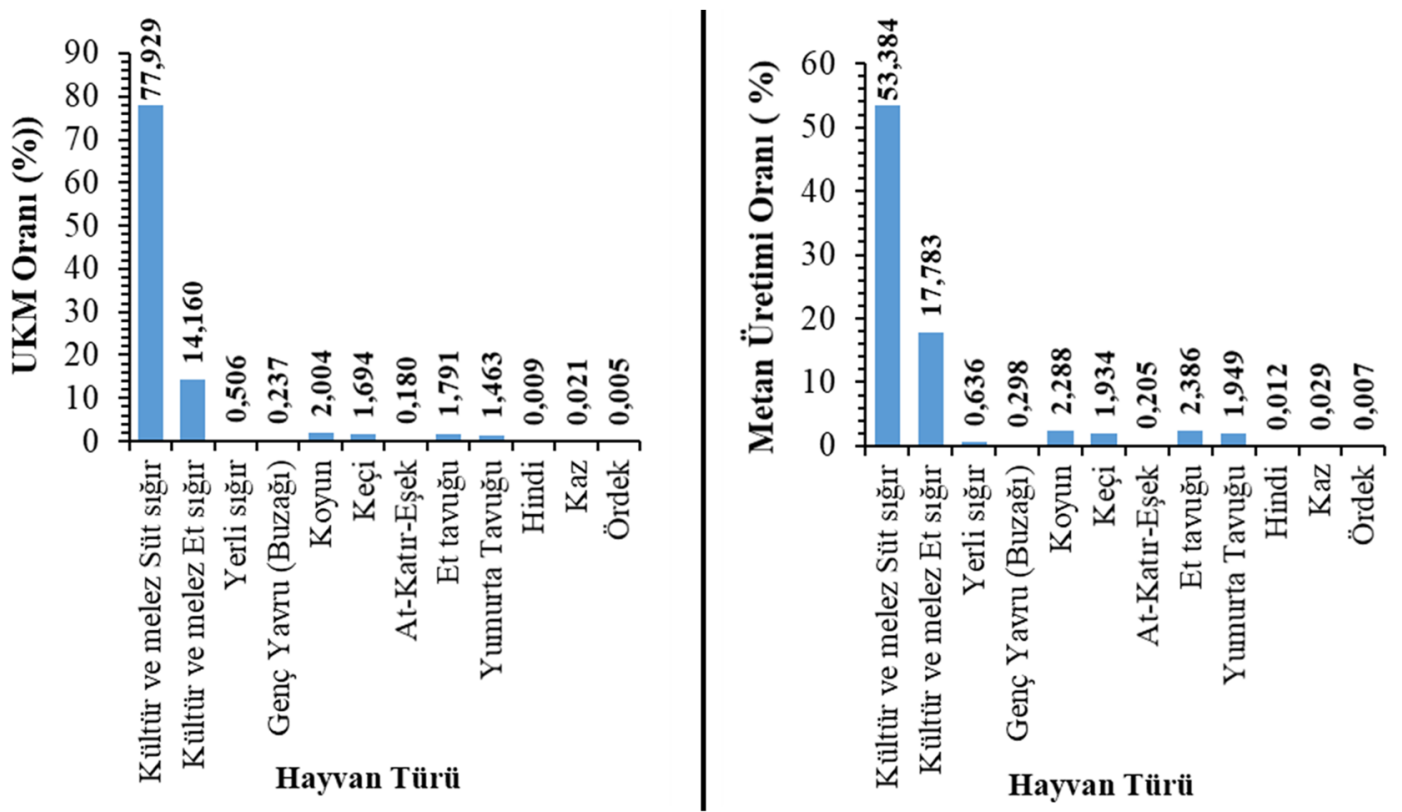

Şekil 3. 2018 yılındaki hayvan türüne bağlı olarak toplanabilir faydalı toplam hayvan gübrelerinin üretilebilecek UKM ve metan oranları

\section{SONUÇ VE ÖNERILER}

Biyogaz üretiminin sürdürülebilir olması için, ekonomik, çevresel ve sosyal bakış açısı gibi birçok faktör vardır. Biyogaz üretiminde, hammadde ve teknoloji uygun olarak kullanılmalı ve anaerobik sindirim için uygun şartların sağlanması gerekmektedir. Biyogaz üretimin yaygınlaştırılması hem enerjide dışa bağımlılı̆̆ zamanda $\mathrm{CO}_{2}$ salınımını azaltarak sera etkisi oluşumuna olumlu etki edecektir. Günümüzde insan sağlığını tehdit eden, çevresel problemlere neden olan organik atıkların değerlendirilmesine ve zararsız hale getirilmesine olanak sağlayan biyogaz güç teknolojilerinin kullanımı önemli bir faktör olarak öne çıkmaktadır.

Temel olarak atık su arıtma tesislerindeki arıtma çamurlarından da üretilebilen biyogazın en temel kaynağı hayvansal atıklardır. Hayvansal atıkların sayılarının, gübre üretim oranlarının ve biyogaz üretim potansiyelinin Adana İli özelinde detaylı olarak ele alındığı bu çalışmada ayrıca üretilen biyogazın CHP motorlarda kullanımı ile elde edilebilecek güç miktarı hesaplanmıştır. $\mathrm{Bu}$ hesaplamalar neticesinde:
- Adana'da toplamda 265.430 adet büyükbaş, 2.643 tek tırnaklı, 807.900 adet küçükbaş, 1.987.019 adet kanatlı olmak üzere toplamda 3.062.992 adet hayvanının bulunduğu, - 2018 y1l1 itibariyle toplamda 3.690.893,47 ton/y1 hayvan gübresinin üretildiği ve bu miktarın 2.919.221,645 ton/yıl'ını büyükbaş, 653.082,875 ton/yıl'ını küçükbaş ve $118.588,952$ ton/yıl'1nı ise kanatlı hayvan gübrelerinin oluşturduğu,

görülmüştür. $\mathrm{Bu}$ veriler ele alınarak yapılan hesaplamalar neticesinde;

- Toplam 3.062.992 adet hayvandan toplam yılda $88.367,417 \mathrm{~m}^{3}$ metan üretilebileceği,

- $\quad$ Bu metan gazının 78.745,94 $\mathrm{m}^{3}$ 'ünün büyükbaş hayvanlardan, 4.611,26 $\mathrm{m}^{3}$ 'ünün küçükbaş hayvanlardan, 223,85 $\mathrm{m}^{3}$ 'ünün tek tırnakl1 hayvanlardan ve 4.786,38 $\mathrm{m}^{3}$ 'ünün kanatlı hayvanlardan üretilebileceğgi,

- 2018 yılında toplanabilir faydalı hayvan gübresinden biyogaz üretimi yapılması sonucu, üretilebilecek toplam metan gazının enerji değerinin 3.181,227 GJ/yıl ve 75,979 TEP/yıl olacağ1 
- Metan gazının ortalama elektrik verimi \%35 olan bir CHP motorunda yakılması ile yılda 309,286 MWhe elektrik üretiminin mümkün olacağ1 görülmüştür. $1 \mathrm{kWh}$ elektrik tasarrufunun yaklaşık olarak $0,58 \mathrm{~kg} \quad \mathrm{CO}_{2}$ salınımına denk geldiği düşünüldüğünde hayvansal atıklardan biyogaz eldesi ile yılda yaklaşık 179,4 ton $\mathrm{CO}_{2}$ salınımının engellenebileceği görülmektedir.

\section{KAYNAKLAR}

1. Enerji ve Tabii Kaynaklar Bakanlığı, Bilgi Merkezi, https://www.enerji.gov.tr/trTR/Sayfalar/Biyokutle (erişim tarihi 01.05.2019).

2. Taleghani, G., Kia, A.S., 2005. Technicaleconomical Analysis of the Saveh Biogas Power Plant. Renewable Energy, 30(3), 441-446.

3. Shane, A., Gheewala, S.H., Kafwembe, Y., 2017. Urban Commercial Biogas Power Plant Model for Zambian Towns. Renewable Energy, 103, 1-14.

4. León, E., Martín, M., 2016. Optimal Production of Power in a Combined Cycle from Manure Based Biogas. Energy Conversion and Management, 114, 89-99.

5. Noorollahi, Y., Kheirrouz, M., Asl, H.F., Yousefi, H., Hajinezhad, A., 2015. Biogas Production Potential from Livestock Manure in Iran. Renewable and Sustainable Energy Reviews, 50, 748-754.

6. Abdeshahian, P., Lim, J. S., Ho, W. S., Hashim, H., Lee, C.T., 2016. Potential of Biogas Production from Farm Animal Waste in Malaysia. Renewable and Sustainable Energy Reviews, 60, 714-723.

7. Scarlat, N., Fahl, F., Dallemand, J. F., Monforti, F., Motola, V., 2018. A Spatial Analysis of Biogas Potential from Manure in Europe. Renewable and Sustainable Energy Reviews, 94, 915-930.

8. Koç, Y., Yağlı, H., Koç, A., 2019. Exergy Analysis and Performance Improvement of a Subcritical/Supercritical Organic Rankine Cycle (ORC) for Exhaust Gas Waste Heat Recovery in a Biogas Fuelled Combined Heat and Power (CHP) Engine through the Use of Regeneration. Energies, 12(4), 575.
9. Yağlı, H., Koç, Y., Koç, A., Görgülü, A., Tandiroğlu, A., 2016. Parametric Optimization and Exergetic Analysis Comparison of Subcritical and Supercritical Organic Rankine Cycle (ORC) for Biogas Fuelled Combined Heat and Power (CHP) Engine Exhaust Gas Waste Heat. Energy, 111, 923-932.

10. Chatzopoulou, M.A., Simpson, M., Sapin, P., Markides, C.N., 2019. Off-design Optimisation of Organic Rankine Cycle (ORC) Engines with Piston Expanders for Medium-scale Combined Heat and Power Applications. Applied Energy, 238, 1211-1236.

11. Weiland, P., 2010. Biogas Production: Current State and Perspectives. Applied Microbiology and Biotechnology, 85(4), 849-860.

12. Cordell, D., Drangert, J.O., White, S., 2009. The Story of Phosphorus: Global Food Security and Food for Thought. Global Environmental Change, 19(2), 292-305.

13. International Energy Agency (IEA) Report December, 2000, Task24- Energy from Biological Conversion of Municipal Solid Waste.

14. Bharathiraja, B., Sudharsana, T., Jayamuthunagai, J., Praveenkumar, R., Chozhavendhan, S., Iyyappan, J., 2018. Biogas Production-A Review on Composition, Fuel Properties, Feed Stock and Principles of Anaerobic Digestion. Renewable and Sustainable Energy Reviews, 90, 570-582.

15. Enerji ve Tabii Kaynaklar Bakanlığı, Enerji İşleri Genel Müdürlüğü, http://www.yegm.gov. tr/yenilenebilir/biyogaz.aspx (Erişim tarihi 01.05.2019).

16. Ilkiliç, C., Deviren, H., 2011. Biyogazın Üretimi ve Üretimi Etkileyen Faktörler. In $6^{\text {th }}$ International Advanced Technologies Symposium (IATS'11), Elazı̆̆g, Turkey, 16-18.

17. Görmüş, C., 2018. Türkiye'deki Hayvan Gübrelerinin Biyogaz Enerji Potansiyelinin Belirlenmesi, Namık Kemal Üniversitesi, Fen Bilimleri Enstitüsü, Yüksek Lisans Tezi, 78. Tekirdağ.

18. Çallı, B., 2012. Atıklardan Biyogaz Üretimi. Türkiye Kimya Derneği-Genç Kimyacılar Platformu, http://mebig.marmara.edu.tr/ Presentations/BiyogazUretimi.pdf. (Erişim tarihi 01.05.2019). 
19. Deublein, D., Steinhauser, A., 2011. Biogas from Waste and Renewable Resources: an Introduction. John Wiley \& Sons, Weinheim.

20. Kaya, D., Öztürk, H. H., 2012. Biyogaz Teknolojisi: $\quad$ Üretim-kullanım-projeleme. Umuttepe Yayınları, İzmit/Kocaeli, 253.

21. Sreekrishnan, T.R., Kohli, S., Rana, V., 2004. Enhancement of Biogas Production from Solid Substrates Using Different Techniques-a Review. Bioresource Technology, 95(1), 1-10.

22. Mutlu, S.F., 2003. Biyogazın Kirsal Kesimde Kullanımı ve Tasarım Temelleri. Türk Tesisat Mühendisleri Derneği Dergisi, 27, 39-41.

23. Dalkılıç, K., Uğurlu, A., 2013. Tavuk Gübresinden Biyogaz Üretimi. Tavukçuluk Araştırma Dergisi, (10), 14-19.

24. Eryaşar, A., Koçar, G., 2009. Biyogaz Üretiminde Basincın Etkisi. Pamukkale Üniversitesi Mühendislik Bilimleri Dergisi, 15(2), 181-186.

25. Cestonaro, T., de Mendonça Costa, M.S.S., de Mendonça Costa, L.A., Rozatti, M.A.T., Pereira, D.C., Lorin, H.E.F., Carneiro, L.J., 2015. The Anaerobic Co-digestion of Sheep Bedding and $\geqslant 50 \%$ Cattle Manure Increases Biogas Production and Improves Biofertilizer Quality. Waste Management, 46, 612-618.

26. Marañón, E., Castrillón, L., Quiroga, G., Fernández-Nava, Y., Gómez, L., García, M.M., 2012. Co-digestion of Cattle Manure with Food Waste and Sludge to Increase Biogas Production. Waste Management, 32(10), 1821-1825.

27. Ekinci, K., Kulcu, R., Kaya, D., Yaldız, O., Ertekin, C., Ozturk, H.H., 2010. The Prospective of Potential Biogas Plants that can Utilize Animal Manure in Turkey. Energy Exploration \& Exploitation, 28(3), 187-205.

28. Enerji ve Tabii Kaynaklar Bakanlığı, Yenilenebilir Enerji Genel Müdürlüğü, Türkiye Biyokütle Enerjisi Potansiyeli Atlası, http://bepa.yegm.gov.tr/ (Erişim tarihi 01.05.2019).

29. Enerji Atlas1, E-Bültenler https://www. enerjiatlasi.com/biyogaz/ (Erişim tarihi 01.05.2019).

30. Enerji Atlası, Adana Yüreğir Sofulu Çöplüğü Biyogaz Santrali Raporu, http://www. enerjiatlasi.com/biyogaz/sofulu-coplugubiyogaz-santrali.html (erişim tarihi 01.05.2019).

31. Türkiye İstatistik Kurumu, Hayvan İstatistik Raporu https://biruni.tuik.gov.tr/medas/?kn= 101\&locale $=\operatorname{tr}$ (erişim tarihi 01.05.2019).

32. Ayhan, A., 2015. Biogas Production Potential from Animal Manure of Bursa Province. Journal of Agricultural Faculty of Uludağ University, 29(2), 47-53.

33. Aktaş, T., Özer, B., Soyak, G., Ertürk, M.C., 2015. Tekirdağ İli'nde Hayvansal Atık Kaynaklı Biyogazdan Elektrik Üretim Potansiyelinin Belirlenmesi. Tarım Makinaları Bilimi Dergisi, 11(1), 69-74.

34. Koc, Y., Yagli, H., Ozdes, E.O., Baltacioglu, E., Koc, A., (in press). Thermodynamic Analysis of Solid Waste and Energy Consumption to Reduce the Effects of an Electric Arc Furnace (EAF) on the Environment. International Journal of Global Warming. 